\title{
Distribution patterns of attached and suspended bacteria in pristine and contaminated shallow aquifers studied with an in situ sediment exposure microcosm
}

\author{
Christian Griebler $^{1,2, *}$, Birgit Mindl ${ }^{1,3}$, Doris Slezak ${ }^{1,4}{ }^{,}$Margot Geiger-Kaiser $^{5}$ \\ ${ }^{1}$ Institute of Limnology, Austrian Academy of Sciences, Gaisberg 116, 5310 Mondsee, Austria \\ ${ }^{2}$ Center for Applied Geoscience, University of Tübingen, Wilhelmstrasse 56, 72074 Tübingen, Germany \\ ${ }^{3}$ Institute of Zoology and Limnology, University of Innsbruck, Technikerstraße 25, 6020 Innsbruck, Austria \\ ${ }^{4}$ Department of Marine Sciences, University of Alabama, Dauphin Island Sea Lab, 101 Bienville Blvd, Alabama 36528, USA \\ ${ }^{5}$ Provincial Government of Salzburg, Section of Water Protection, PO Box 527, 5010 Salzburg, Austria
}

\begin{abstract}
We used specially designed microcosms filled with natural substrate to study microbial colonization in a shallow aquifer. Sterilized sediments were exposed to 3 types of groundwater varying in physical, chemical and biological characteristics: (1) pristine groundwater (site PI 92); (2) groundwater in an observation well at a pristine site (OMV 11); and (3) contaminated groundwater at a landfill site (OMV 5). The number of suspended bacteria was always highest at the landfill site $(4.0 \pm 4.2$ [standard deviation, $\left.\mathrm{SD}] \times 10^{6} \mathrm{cells}^{-3}\right)$, i.e. on average 16 times higher than in the well

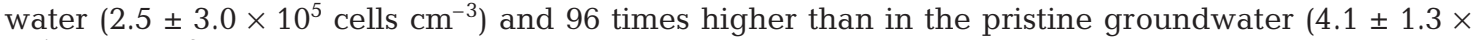
$10^{4} \mathrm{cells} \mathrm{cm}^{-3}$ ). Sediments in the microcosms were rapidly colonized and the total number of attached bacteria after 10 mo of exposure was highest at the landfill site $\left(1.8 \pm 0.4 \times 10^{8}\right.$ cells cm$\left.{ }^{-3}\right)$ followed by the sediment incubated in well water $\left(1.5 \pm 0.5 \times 10^{8} \mathrm{cells} \mathrm{cm}^{-3}\right)$ and in pristine groundwater $(5.0 \pm$ $1.5 \times 10^{7} \mathrm{cells} \mathrm{cm}^{-3}$ ). As estimated from image analysis, attached cells from the landfill site were on average characterized by higher cell carbon contents $\left(28 \pm 36 \mathrm{fg} \mathrm{C}\right.$ cell $\left.{ }^{-1}\right)$ than at the well water $(24 \pm$ $\left.23 \mathrm{fg} \mathrm{C} \mathrm{cell}^{-1}\right)$ and the pristine groundwater site $\left(21 \pm 23 \mathrm{fg} \mathrm{C} \mathrm{cell}^{-1}\right)$. The ratio of attached to suspended bacteria after 10 mo of exposure was highest in the microcosm incubated in pristine groundwater (1657:1) and lowest at the contaminated site (59:1). On the basis of our results we emphasize the importance of attached microbial communities in porous subsurface systems and underline the need for groundwater as well as sediment samples for a serious microbiological characterization of the subsurface. Furthermore, the ratio of attached to suspended bacteria in shallow aquifer systems is suggested to be an indicator of prevailing nutrient concentrations.
\end{abstract}

KEY WORDS: Bacteria $\cdot$ Subsurface $\cdot$ Biofilms $\cdot$ Colonization $\cdot$ Microcosm $\cdot$ Groundwater $\cdot$ Method

\section{INTRODUCTION}

The subsurface hides an invisible but enormous amount of living biomass. Comparing the prokaryotic biomass of the most prominent habitats of our biosphere, Whitman et al. (1998) underlined the outstand-

*Present address: Center for Applied Geoscience, University of Tübingen, Wilhelmstrasse 56, 72074 Tübingen, Germany. E-mail: christian.griebler@uni-tuebingen.de ing importance of marine and terrestrial subsurface systems. Based on their data, 92 to $95 \%$ of the earth's prokaryotic biomass exists in the subsurface. Estimates by Gold (1992) indicate that the subsurface may harbor almost the same amount of total biomass as, or even more than, surface ecosystems. In the context of strong human impacts on the environment, the high purification potential of groundwater ecosystems is of increasing interest and importance. This purification service is almost exclusively provided by indigenous micro- 
organisms. Nevertheless, because of the inaccessibility of the subsurface, our knowledge about the underground microbial community, its ecology and its role in turnover of matter is still poor.

Groundwater studies often focus on chemical and biological characteristics of the water pumped from the aquifer. In recent publications, however, it turned out that sediment porewater samples are not sufficient to describe the microbiology of saturated subsurface sediment systems (Alfreider et al. 1997, Lehman et al. 2001a). Suspended bacteria seem to contribute only 0.01 to $10 \%$ of the total bacterial community or biomass in pristine and contaminated aquifers (Marxsen 1982, Harvey et al. 1984, Kölbel-Boelke et al. 1988, Hazen et al. 1991, Alfreider et al. 1997), while most of the bacteria are associated with particles. Consequently, biofilm communities are supposed to control the flux of matter in the subsurface. Nevertheless, studies focusing on the distribution of microorganisms in the saturated subsurface are scarce (Marxsen 1982, Harvey et al. 1984, Kölbel-Boelke et al. 1988, Hazen et al. 1991, Amy et al. 1992, Godsy et al. 1992, Hirsch \& Rades-Rohkohl 1992, Kölbel-Boelke \& Nehrkorn 1992, Albrechtsen 1994, Alfreider et al. 1997, Bekins et al. 1999, Lehman et al. 2001b), which is mostly due to difficult access to subsurface samples. In general, sampling of sediment requires expensive mining and drilling activities (Wilson et al. 1983, Griffin et al. 1997, Russell 1997). Furthermore, these techniques do not allow repeated sampling of a single site (same borehole) and thus one does not have the chance to study attached microbial communities over time in situ, which is a drawback of sediment studies in general. To overcome these problems, attempts have been made to develop alternative techniques, such as the exposure of substratum to groundwater. The development and fate of biofilms or microbial colonization was studied via introduction of sterilized material such as glass slides or beads (Claret 1998a,b) and sediments of different grain size (Marxsen 1982, Hirsch \& Rades-Rohkohl 1990, Doig et al. 1996, Alfreider et al. 1997) into permanently installed groundwater wells. Since the composition and activity of microbial communities in well water were shown to differ significantly from those of the adjacent aquifer porewater (McNabb \& Mallard 1984, Hirsch \& RadesRohkohl 1988, 1990, Hirsch et al. 1992), pronounced differences may also be expected to occur when attached microbial communities from aquifers and embedded wells are compared. Furthermore, microbial colonization on artificial material (e.g. glass slides and beads, silica particles, metallic surfaces, plastic substrata) is not directly comparable to the attachment of microbes and the subsequent development of biofilms on sediment particles and other natural surfaces present in the environment (Bengtsson 1989, Scholz \& Boon 1993, Bennett et al. 2000).
In situ techniques for the investigation of subsurface microorganisms are scarce. Shati et al. (1996) described small chambers (microcosms) equipped with semi-permeable membranes that can be supplied with single bacterial strains or microbial communities and introduced to certain depths into the subsurface within multi-level groundwater wells. The crucial point in these investigations is to follow the physiological response of the microorganisms exposed to groundwater under in situ conditions. A different kind of in situ microcosm, based on the inclusion of natural subsurface material by a sediment catcher at the bottom of a pre-drilled borehole, was described by Nielsen et al. (1996). The encased sediment remains at the site and can then be loaded with organic contaminants and/or inorganic nutrients. Subsamples can be taken frequently for sediment porewater to follow in situ degradation of contaminants. The sediment matrix and its associated microbes can only be examined at the end of each experiment.

To study the development and fate of biofilms in subsurface sediment systems, we developed an in situ sediment exposure microcosm (ISSEM), a simple and inexpensive tool that allowed us to follow the microbial colonization of natural sediments in situ. Microcosms were exposed to pristine groundwater, water in a groundwater observation well and contaminated groundwater at a landfill site. This paper presents data on the distribution and size of bacteria between the surface of sediment particles and the porewater in groundwater environments differing in conditions.

\section{MATERIALS AND METHODS}

Site description. The investigated aquifer is located near the villages of Anif and Niederalm (13 $54^{\prime} \mathrm{E}$, $47^{\circ} 45^{\prime} \mathrm{N}$ ) south of the city of Salzburg, Austria. Microcosm experiments were performed using 3 multi-level groundwater monitoring wells established in 1987 (wells OMV 5 and OMV 11) and 1992 (well PI 92) on behalf of the local county of Salzburg. These wells are part of a dense net of groundwater observation wells within and surrounding a small landfill. Well OMV 11 is located upgradient and well PI 92 downgradient of the landfill with respect to the proposed groundwater flow direction, while well OMV 5 is located in the center of the landfill area (Fig. 1). The aquifer is formed by alluvial quaternary sediments. A rough vertical sediment distribution can be outlined as follows: from the soil horizon to a depth of $1.5 \mathrm{~m}$, a sandy and gravelly humus soil layer is found. The underlying sediments are gravel and sand deposits, which have distinct layers (i.e. 1.5 to 5,5 to 20,20 to $50 \mathrm{~m}$ ) defined by decreasing mean grain sizes with depth (from coarse 


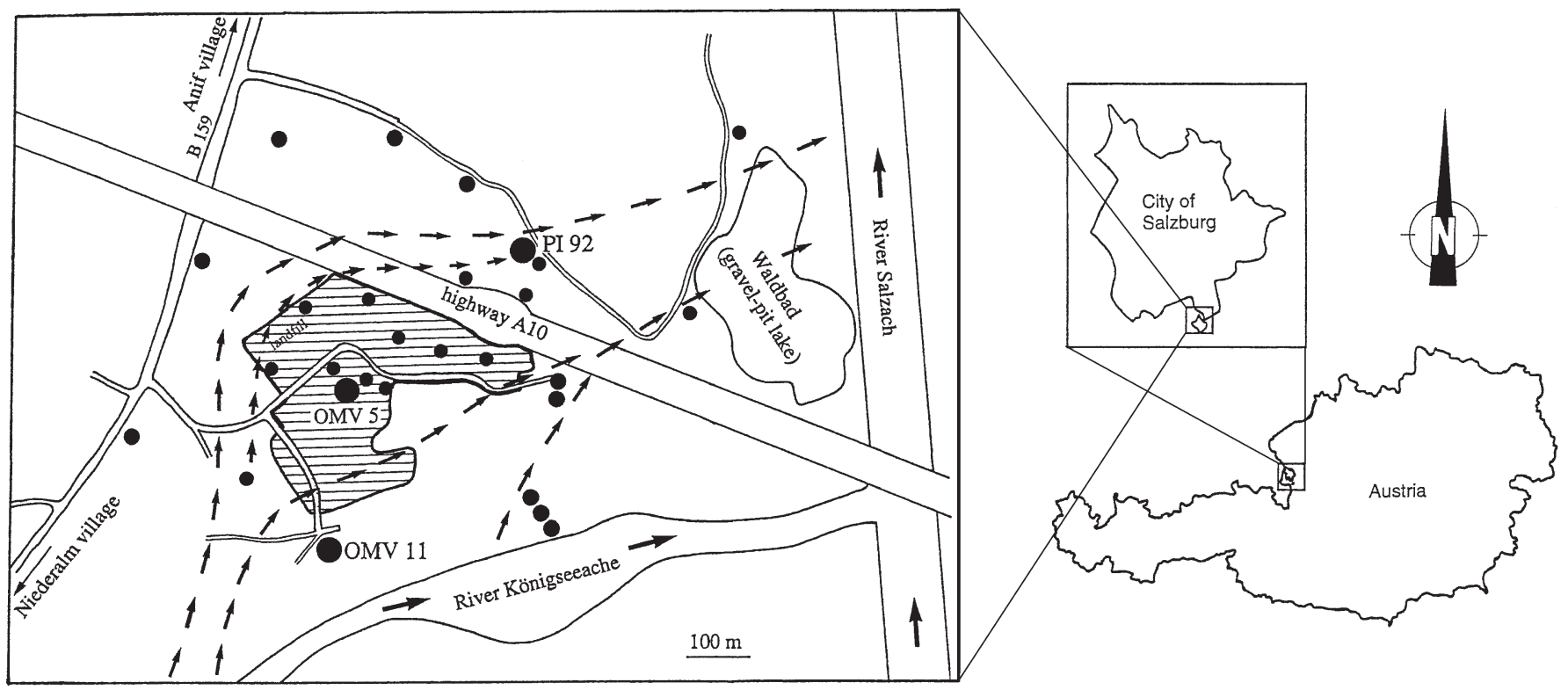

Fig. 1. Location of the study site, with the landfill area depicted with stripes. Arrows indicate the direction of the groundwater flow. In addition to the 3 big dots representing the investigation wells, smaller dots indicate further groundwater observation wells not sampled in this study

gravel with some sand content to smaller gravel with a high content of sand and silt) (OMV Corp. 1987).

The Anif landfill originates from a gravel production during the years 1970 to 1977 . The resulting gravel pit was continuously refilled with rubbish, debris, barrels and car wrecks between 1975 and 1983. Today the landfill covers an area of $90000 \mathrm{~m}^{2}$. A humus and compost soil layer on top is followed by rubbish to a mean depth of about $12 \mathrm{~m}$ (maximum $18 \mathrm{~m}$ ), where it meets the quaternary sediments. The landfill is only partly sealed to the adjacent aquifer.

Exposure of sediments and groundwater sampling. The ISSEM was modified from a double-packer groundwater sampler introduced by Danielopol \& Niederreiter (1987) for the exposure of sediments to 'true' groundwater (in contrast to well water). The ISSEM consisted of a cylindrical stainless metal sieve $(\mathrm{r}=2.5 \mathrm{~cm}, \mathrm{~h}=15 \mathrm{~cm}, 600 \mu \mathrm{m}$ mesh size), which in our case was filled with heat-sterilized $\left(450^{\circ} \mathrm{C}, 4 \mathrm{~h}\right)$ coarse sand (grain size 600 to $2000 \mu \mathrm{m}$ ) originating from a small brook with a geologic background similar to that of the aquifer material. Two inflatable rubber packing rings fixed the microcosms within the multi-level monitoring wells (inner diameter $6 \mathrm{~cm}$ ) at a depth of $7 \mathrm{~m}$ beneath the soil horizon. The inflated rubber rings separated the incubated sediments from well water (Fig. 2), and an electric peristaltic pump maintained a moderate but permanent flow of aquifer porewater through the microcosm of about $200 \mathrm{ml} \mathrm{d}^{-1}$, which equates to a porewater residence time of half a day. The exposed substratum was therefore permanently in contact with fresh groundwater. At well OMV 11, the rubber packing rings were not inflated and the sediment was therefore exposed to well water. Sediment porewater from the microcosm $(300 \mathrm{ml})$ was sampled by simply collecting the pumped groundwater after the dead volume of the tubings $(\sim 70 \mathrm{ml})$ was quickly replaced (pumping rate $35 \mathrm{ml} \mathrm{min}{ }^{-1}$ ). The first $100 \mathrm{ml}$ of the sample was used for the determination of physical-chemical parameters (temperature, $\mathrm{pH}$, specific conductivity, dissolved oxygen) with field sensors (WTW), and the remaining $200 \mathrm{ml}$ porewater was used for microbiological investigations. The subsequent groundwater, which was pumped fresh from the aquifer ( 0.5 to 1 l), was used for chemical analysis. Thereafter, sediment was subsampled during a short retrieval of the ISSEM from the well. Microcosms PI 92 and OMV 5 were temporarily (PI 92: 12 October to 7 December; OMV 5: entire investigation period) equipped with a sensor for hydrostatic pressure and temperature connected to a datalogger system. Field microcosm studies took place between September and December 1998 and exposed sediments were subsampled in $2 \mathrm{wk}$ intervals for a total of $14 \mathrm{wk}$. An additional and final sampling of the ISSEM, which was left in the subsurface for another $6.5 \mathrm{mo}$, was performed in June 1999.

Chemical analysis. Major anions and cations were analyzed by ion chromatography in a single column mode (IC 120, Dionex).

The volatile monoaromatic compounds benzene, toluene, ethylbenzene and xylene (BTEX) and halo- 
genated organic compounds (HOC) were quantified from headspace analysis with a gas chromatograph (model 5890 Series II, Hewlett Packard) equipped with a flame ionization detector and a fused silica capillary column (optima $\delta$-3; length $60 \mathrm{~m}$, inner diameter $0.32 \mathrm{~mm}$, film thickness $0.35 \mu \mathrm{m}$, MachereyNagel).

Bacterial abundance and biomass measurements. Ten milliliters of pristine or $1 \mathrm{ml}$ of contaminated sediment porewater was subsampled in duplicate for total bacterial counts following the protocol of Porter \& Feig (1980). The total number of attached bacteria was determined in duplicates as follows: $1 \mathrm{~cm}^{3}$ of sediment was carefully washed with bacteria-free $(0.2 \mu \mathrm{m})$ sample water to replace remaining sediment interstitial water and suspended cells. Attached bacteria were released from particle surfaces by shaking and sonicating the sediment samples in the presence of $100 \mathrm{mM}$ tetrasodium pyrophosphate. A $90 \%$ recovery of initially attached cells was demonstrated for coarse sand samples (Griebler et al. 2001). The same sediment type was used in this study; thus, total bacterial counts were corrected by a factor of 1.1. Cells were stained with 4',6-diamidino-2-phenylindole (DAPI) and SYBR Green II as fluorescence dyes, counted under the epifluorescence microscope and measured by image analysis. Cell-length and -width measurements were used for an automatic calculation of the cell biovolumes (Posch et al. 1997). Conversion factors given in Loferer-Krößbacher et al. (1998) were applied for carbon content calculations. At least 200 cells of each sample were recorded. To provide a direct comparison of the number of attached versus suspended bacteria, cell counts are expressed on a volume basis. As the porosity of our coarse sand fraction was determined to be $40 \%$, values of unattached bacteria $\mathrm{cm}^{-3}$ represented the number of cells suspended in $400 \mu \mathrm{l}$ of sediment porewater. The wet weight of $1 \mathrm{~cm}^{3}$ of sediment was about $2 \mathrm{~g}$, which equaled approximately $1.6 \mathrm{~g}$ dry weight.

Statistical analysis. Statistical analysis was performed using the Jandel Sigma Stat 2.0 software package. Individual data points or series were compared to each other by simple $t$-tests. Correlation analysis was performed by means of a Spearman rank correlation matrix.

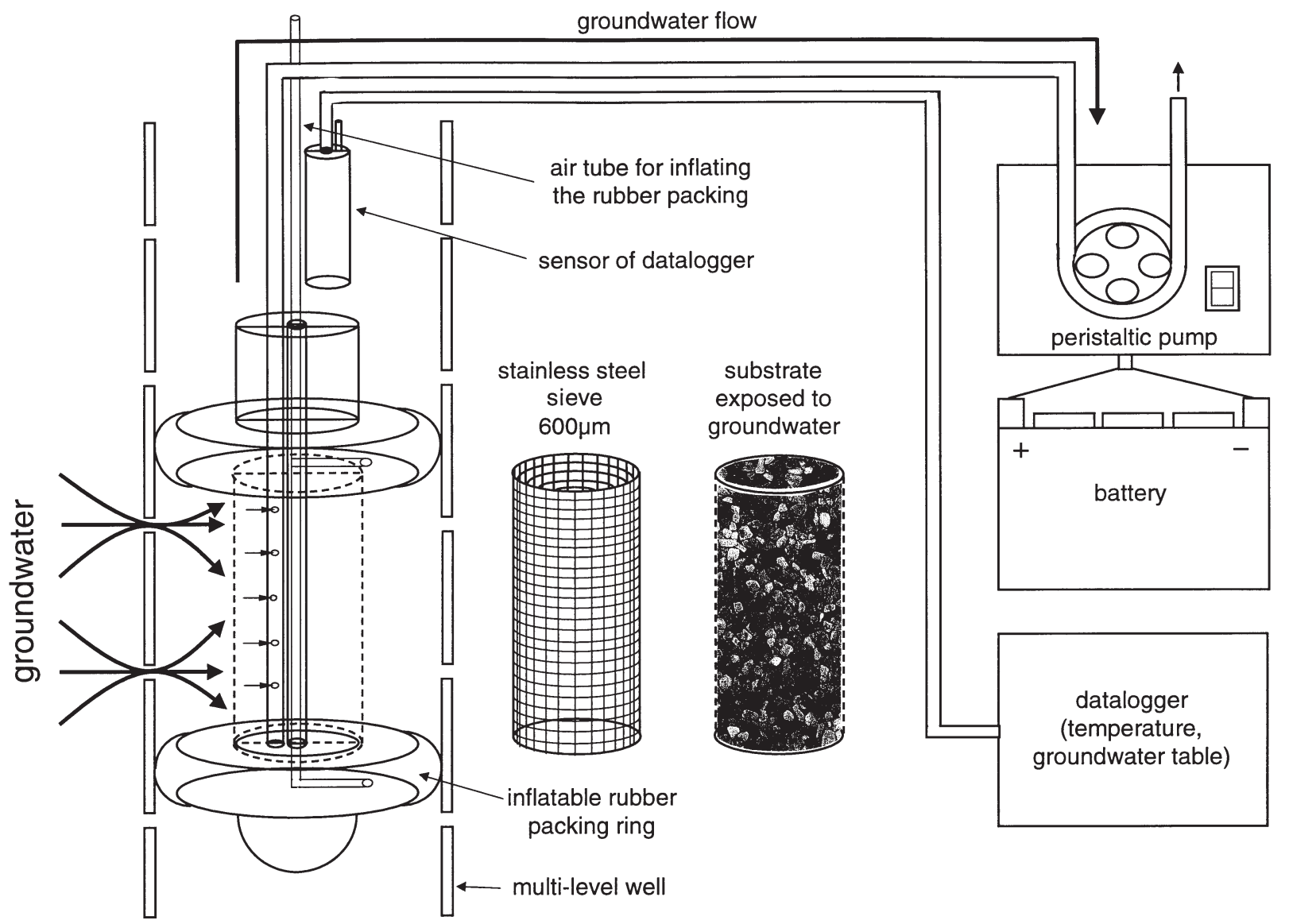

Fig. 2. Schematic drawing of the in situ sediment exposure microcosm (ISSEM) 


\section{RESULTS}

\section{Physical and chemical conditions at the 3 investigation sites}

Physical and chemical parameters at the pristine sampling sites OMV 11 and at PI 92 were significantly different from the landfill site OMV 5 ( $t$-test, $\mathrm{p}<0.001$, $\mathrm{n}=8$ ), with temperature being the only exception. No significant differences could be detected between OMV 11 and PI 92, apart from slightly higher nitrate concentrations at PI 92 ( $t$-test, $\mathrm{p}<0.001, \mathrm{n}=8$; Table 1 ). In general, OMV 11 and PI 92 both showed features typical of shallow pristine groundwater sites, i.e. sufficient oxygen and low nutrient concentrations. Nevertheless, HOC and monoaromatic hydrocarbons (benzene, toluene and $m-/ p$-xylene) were detected once in trace amounts, but were below the legal limit concentrations for groundwater (FSPO 1999). The landfill aquifer exhibited hypoxic conditions during the first 8 wk of our study with oxygen concentrations between 0.1 and $0.3 \mathrm{mg} \mathrm{l}^{-1}$. From November onward, oxygen concentrations slightly increased to between 1.1 and $2.1 \mathrm{mg} \mathrm{l}^{-1}$. At OMV 5, significant positive correlations were observed between the oxygen concentration, groundwater table fluctuations (Spearman rank correlation, $\mathrm{R}=0.829, \mathrm{p}<0.05)$ and groundwater tempera- ture $(\mathrm{R}=0.812, \mathrm{p}<0.05)$, respectively. The groundwater at the landfill was further characterized by high concentrations of ammonium, sulfate and dissolved organic carbon (DOC) (Table 1). The total amount of organic contaminants (HOC, BTEX) was significantly higher than at PI 92 and OMV 11 (Student's t-test, p < 0.05), but still at very low concentrations (Table 1). Rainfall had a marked influence on groundwater table fluctuations at all investigation sites, and therefore a strong positive correlation to groundwater temperature until the middle of October (warm season) and a negative one with the beginning of the cold season was observed (Fig. 3). At the landfill site, groundwater table fluctuations of more than $1.5 \mathrm{~m}$ occurred within $24 \mathrm{~h}$, and a maximum temperature change of $4^{\circ} \mathrm{C}$ within $2 \mathrm{~h}$ could be detected after heavy rainfalls at a depth of $7 \mathrm{~m}$ beneath the soil horizon and 3 to $4 \mathrm{~m}$ below the groundwater table. Fluctuations observed in the surrounding aquifer during the same time were at most a few centimeters and a few tenths of a degree Celsius (Fig. 3).

\section{Bacteria from sediment porewater}

The pristine groundwater from PI 92 was characterized by significantly lower bacterial densities with a

Table 1. Physical and chemical data of the 3 investigated sites $(n=9)$. BTEX: Monoaromatic hydrocarbons (benzene, toluene, ethylbenzene, xylenes); DOC: dissolved organic carbon; HOC: halogenated organic compounds; nd: not determined. *Values in brackets are extraordinarily high values determined only once (12 October 1998); ${ }^{* *}$ Absent or below the mentioned detection limit of the analysis; ${ }^{* * *}$ Single measurement above the corresponding detection limit of the method during the entire time of the experiments. BTEX and HOC data originated from sampling surveys in April 1998 and May 1999

\begin{tabular}{|c|c|c|c|c|c|c|c|c|c|}
\hline & \multicolumn{3}{|c|}{-PI 92} & \multirow{2}{*}{$\overline{\text { Min. }}$} & \multicolumn{2}{|c|}{ OMV $11-$} & \multicolumn{3}{|c|}{-OMV $5-$} \\
\hline & Min. & Mean & Max. & & Mean & Max. & Min. & Mean & Max. \\
\hline Temp. $\left({ }^{\circ} \mathrm{C}\right)$ & 8.0 & 9.2 & 12.9 & 8.6 & 11 & 14.7 & 9.4 & 10.1 & 11.9 \\
\hline $\mathrm{pH}$ & 7.6 & 7.8 & 7.9 & 7.4 & 7.8 & 8.2 & 5.1 & 6.8 & 7.4 \\
\hline Specific conductivity $\left(\mu \mathrm{S} \mathrm{cm}^{-1}\right)$ & 268 & 366 & 441 & 221 & 309 & 353 & 597 & 1185 & 1821 \\
\hline $\mathrm{O}_{2}\left(\mathrm{mg} \mathrm{l}^{-1}\right)$ & 5.9 & 7.7 & 8.3 & 5.4 & 7.9 & 10 & 0.1 & 1.2 & 2.1 \\
\hline $\mathrm{HCO}_{3}^{-}\left(\mathrm{mg} \mathrm{l}^{-1}\right)$ & 196 & 221 & 256 & 160 & 185 & 210 & 369 & 793 & 1160 \\
\hline $\mathrm{NO}_{3}^{-}\left(\mathrm{mg} \mathrm{l}^{-1}\right)$ & 4.5 & 4.9 & 5.1 & 3.0 & 3.5 & 4.8 & 0.1 & 1.1 & $5.8(311)^{*}$ \\
\hline $\mathrm{NO}_{2}^{-}\left(\mathrm{mg} \mathrm{l}^{-1}\right)$ & - & $<0.15^{* *}$ & - & - & $<0.15^{* *}$ & - & - & $<0.15^{* *}$ & - \\
\hline $\mathrm{NH}_{4}^{+}\left(\mathrm{mg} \mathrm{l}^{-1}\right)$ & 0.006 & 0.025 & 0.09 & 0.005 & 0.02 & 0.04 & 0.2 & 15.6 & 41.9 \\
\hline $\mathrm{PO}_{4}{ }^{3-}\left(\mathrm{mg} \mathrm{l}^{-1}\right)$ & - & $0.013^{* * *}$ & * $\quad-$ & 0.006 & 0.02 & 0.03 & - & $<0.0037^{* *}$ & - \\
\hline $\mathrm{SO}_{4}^{2-}\left(\mathrm{mg} \mathrm{l}^{-1}\right)$ & 5.8 & 12.6 & 14.1 & 10.2 & 11.9 & 13.9 & 2.2 & 18.5 & $73.6(1130)^{*}$ \\
\hline Fe $\left(\mathrm{mg} \mathrm{l}^{-1}\right)$ & 0.03 & 1.9 & 6.7 & 0.03 & 0.17 & 0.4 & 0.8 & 25 & 36.3 \\
\hline $\operatorname{Mn}\left(\mathrm{mg} \mathrm{l}^{-1}\right)$ & 0.2 & 0.4 & 0.6 & - & $0.06^{* * *}$ & - & 0.3 & 1.14 & 1.7 \\
\hline $\mathrm{DOC}\left(\mathrm{mg} \mathrm{l}^{-1}\right)$ & 0.7 & 1.4 & 3.3 & 0.7 & 1.3 & 1.7 & 6.4 & 13.6 & 21 \\
\hline $\mathrm{HOC}\left(\mu \mathrm{g}^{-1}\right)$ & 2 & \multicolumn{2}{|l|}{2.5} & 1.3 & 2.4 & 3.2 & 5.7 & 15.9 & 22 \\
\hline BTEXs & $\underline{21.04}$ & $\underline{10.0}$ & 05.99 & $\underline{21.0}$ & .98 & 05.99 & 21. & 04.98 & 10.05 .99 \\
\hline Benzene $\left(\mu \mathrm{g}^{-1}\right)$ & $<0.0$ & $<0$. & $03^{* *}$ & 0. & & $03^{* *}$ & & 0.5 & nd \\
\hline Toluene $\left(\mu \mathrm{g} \mathrm{l}^{-1}\right)$ & 0.1 & $<0$ & $03^{* *}$ & 0 & & $03^{* *}$ & & 0.9 & nd \\
\hline Ethylbenzene $\left(\mu \mathrm{g} \mathrm{l}^{-1}\right)$ & $<0.0$ & $<0$ & $04^{* *}$ & $<0$. & $3^{* *}$ & $04^{* *}$ & & 3.7 & nd \\
\hline$m-/ p$-xylene $\left(\mu \mathrm{g} \mathrm{l}^{-1}\right)$ & 0.2 & $\mathrm{n}$ & ad & 0. & & ad & & 1.4 & nd \\
\hline$o$-xylene $\left(\mu \mathrm{g}^{-1}\right)$ & 0.2 & $<0$. & $03^{* *}$ & $<0$ & $3^{* *}$ & $03^{* *}$ & & 1.7 & nd \\
\hline
\end{tabular}



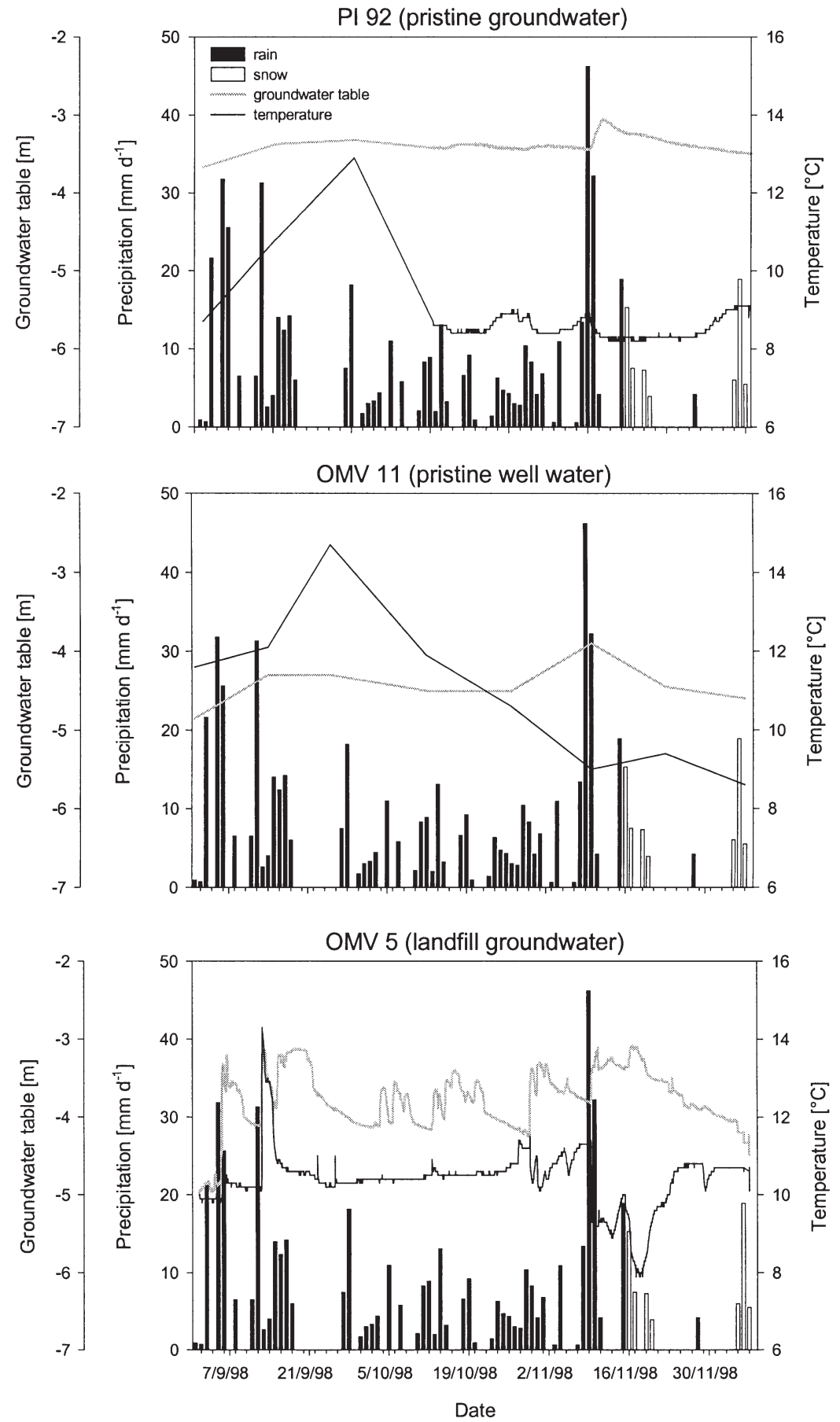

Fig. 3. Hydrological pattern and groundwater temperatures observed at the sampling sites. At site PI 92, groundwater table fluctuations and temperature data were temporarily recorded using a datalogger. At site OMV 5, dataloggers were applied for the entire investigation period. Dates given as $\mathrm{d} / \mathrm{mo} / \mathrm{yr}$

mean \pm standard deviation $(\mathrm{SD})$ of $4.1 \pm 1.3 \times 10^{4}$ suspended cells $\mathrm{cm}^{-3}$ of sediment, compared to the well water from OMV 11 with a mean of $2.5 \pm 3.0 \times 10^{5}$ cells $\mathrm{cm}^{-3}$ ( $t$-test, $\left.\mathrm{p}=0.001\right)$ during sampling from Weeks 0 to 40 . The bacterial cell density at the land- fill site was $4.0 \pm 4.2 \times 10^{6}$ suspended cells $\mathrm{cm}^{-3}$ of sediment and therefore on average 96 and 16 times higher than at PI 92 and OMV 11, respectively (Fig. 4A). Again, there was a significant difference between counts from PI 92 and OMV 5 ( $t$-test, p < 0.001), but no difference between OMV 11 and OMV 5 ( $t$-test, $p=0.965$ ). No clear relationship was observed for bacterial counts and physical and/or chemical parameters determined at the 3 sampling sites, apart from OMV 11, where the changes in suspended bacteria were positively correlated with groundwater table fluctuations (Spearman rank correlation, $\mathrm{R}=0.723, \mathrm{p}<0.05$ ); i.e. an increasing groundwater table went along with higher counts of suspended bacteria.

\section{Colonization of sediment}

At the pristine sites PI 92 and OMV 11, the number of attached bacteria increased continuously and rapidly with time, reaching a clear maximum after 6 wk of sediment exposure (Fig. 4B). After this peak, counts of attached bacteria dropped and balanced at values preceding the peak (Week 4). These values remained constant for the rest of the $14 \mathrm{wk}$ investigation period. An additional sampling after 10 mo revealed a further 2.5and 3.8-fold increase in the number of attached bacteria at PI 92 and at OMV 11, respectively, compared to preceding values at Week 14 (Fig. 4B). Final values of attached cells were $5.0 \pm 1.5 \times 10^{7}$ cells cm$^{-3}$ at PI 92 and $1.5 \pm 0.5 \times 10^{8}$ cells $\mathrm{cm}^{-3}$ at OMV 11. A positive correlation between the number of attached bacteria from OMV 11 and PI 92 underlined the obviously similar colonization patterns (Spearman rank correlation, $\mathrm{R}=0.857, \mathrm{p}<0.01$ ). After $14 \mathrm{wk}$ of exposure, sediment incubated in landfill groundwater (OMV 5) contained 8.6 times and 5.4 times more attached bacteria than sediments incubated in well water (OMV 11) and pristine groundwater (PI 92), respectively. The peak in cell counts observed at PI 92 and OMV 11 was also detected at the landfill site OMV 5, but in this case the number of attached bacteria increased stepwise, with a later maximum after $10 \mathrm{wk}$ of sediment incubation (Fig. 4B). Subsampling of the microcosm sediments at OMV 5 after 10 mo found no significant changes in 
the total number of attached cells ( $t$-test, $\mathrm{p}=0.484$ ) when compared to values determined after $14 \mathrm{wk}$ of sediment exposure (Fig. 4B). Sediments incubated in landfill water finally contained $1.8 \pm 0.4 \times 10^{8}$ cells $\mathrm{cm}^{-3}$.

Cell-size patterns of attached bacteria, which were determined for samples from Weeks 2 to 14, showed that the cells from the landfill site OMV 5 were on average longer than cells from the pristine sites PI 92 and OMV 11 ( $t$-test, $\mathrm{p}<0.001, \mathrm{n}=$ 7; Table 2). No significant differences were detected in cell-width dimensions (Fig. 5A). As a result of cell-size differences, the mean cell carbon content of attached bacteria was found to be significantly higher at the landfill site than at PI 92 ( $t$-test, $\mathrm{p}=0.038, \mathrm{n}=7$ ), but not significantly different from OMV 11. The highest carbon content were calculated for attached bacteria from OMV 5, with $27.7 \pm$ $35.6 \mathrm{fg} \mathrm{C} \mathrm{cell}^{-1}$, followed by the well water bacteria, with $23.7 \pm 23.4 \mathrm{fg} \mathrm{C}$, and the bacteria from PI 92 sediment, with $20.9 \pm$ $22.8 \mathrm{fg} \mathrm{C}$ cell $^{-1}$ (Fig. 5B, Table 2).

\section{Attached versus unattached bacteria}

Ratios of attached to suspended bacteria were clearly different between the 3 microcosms. Nevertheless, a statistically significant difference was found between PI 92 and OMV 5 ratios only ( $t$-test, $\mathrm{p}=0.006$ ). After 10 mo of sediment exposure, the highest values were obtained at the pristine groundwater site PI 92, with a ratio of $1657: 1$, followed by the well water site at OMV 11, with a ratio of 785: 1 , and the lowest ratio of 59:1 at the landfill site OMV 5 (Fig. 6). As can be seen in Fig. 6, the pattern of the ratio curves were similar over time in all microcosms, with a maximum peak

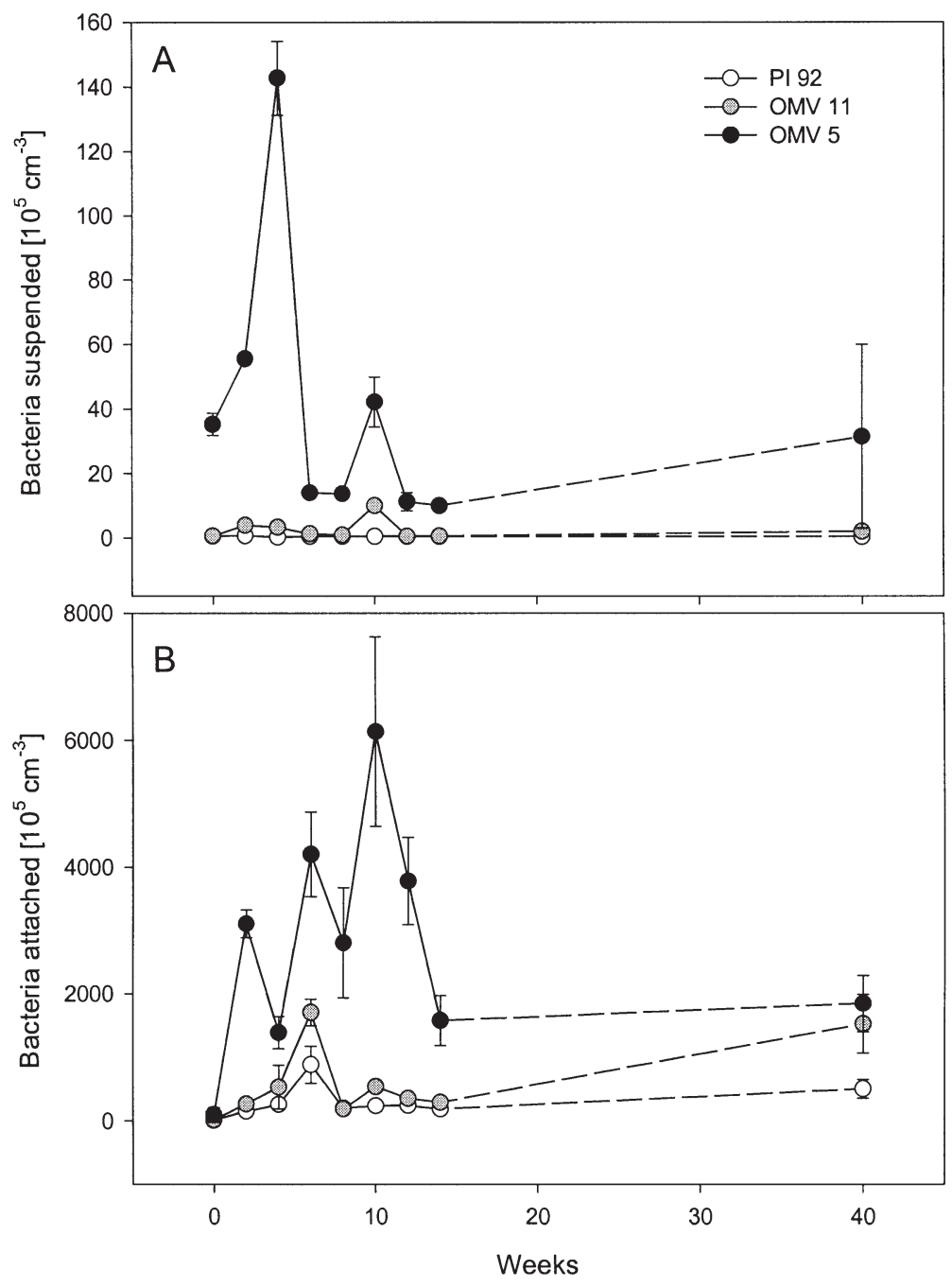

Fig. 4. Total number of (A) suspended and (B) attached bacteria as observed in the exposed sediment at the 3 investigation sites over a period of $14 \mathrm{wk}$ and an additional sampling after a total incubation period of 10 mo. Values are means \pm standard deviation (SD)

after 6 wk of incubation. While OMV 5 and OMV 11 remained more or less constant thereafter, the ratio at PI 92 increased again from 500 to 1657 from Week 14 to Week 40 .

Table 2. Detailed bacterial data from the 3 investigation sites. AB: attached bacteria; SB: suspended bacteria. Values are means \pm standard deviation (SD). For $\mathrm{AB}$, minimum and maximum values are given because of the continuous colonization

\begin{tabular}{|lcrrrr|}
\hline & PI 92 & OMV 11 & OMV 5 & n & Samples considered \\
\hline Total number of $\mathrm{SB}\left(10^{5} \mathrm{~cm}^{-3}\right)$ & $0.41 \pm 0.13$ & $2.53 \pm 3.04$ & $39.53 \pm 41.81$ & 9 & Weeks 0-40 \\
Total number of AB $\left(10^{5} \mathrm{~cm}^{-3}\right)$ & $8.0-880$ & $12-1703$ & $94-6136$ & 9 & Weeks 0-40 \\
Cell length of AB $(\mu \mathrm{m})$ & $0.76 \pm 0.49$ & $0.85 \pm 0.80$ & $1.17 \pm 1.18$ & 7 & Weeks 2-14 \\
Cell width of AB $(\mu \mathrm{m})$ & $0.34 \pm 0.11$ & $0.36 \pm 0.11$ & $0.34 \pm 0.12$ & 7 & Weeks 2-14 \\
Cell volume of AB $\left(\mu \mathrm{m}^{3}\right)$ & $0.07 \pm 0.02$ & $0.08 \pm 0.01$ & $0.09 \pm 0.02$ & 7 & Weeks 2-14 \\
Carbon content of $\mathrm{AB}\left(\mathrm{fg}\right.$ cell $\left.{ }^{-1}\right)$ & $20.9 \pm 22.8$ & $23.7 \pm 23.4$ & $27.7 \pm 35.6$ & & Weeks 2-14 \\
\hline
\end{tabular}



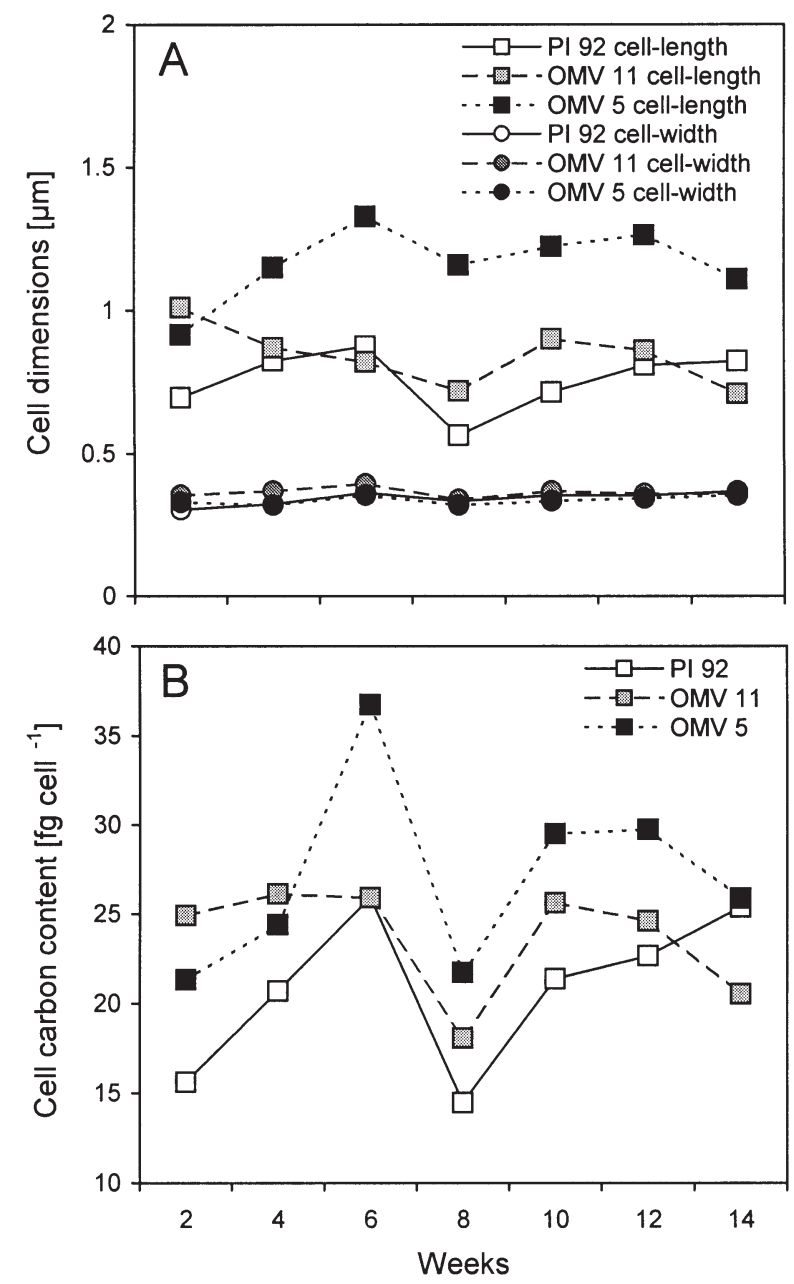

Fig. 5. (A) Cell-length (squares) and cell-width (circles) measurements of attached bacteria and (B) cell carbon contents as calculated using the conversion factor $\mathrm{CC}=218 \times$ $\mathrm{V}^{0.86}$, where $\mathrm{CC}$ is carbon content and $\mathrm{V}$ is biovolume; see Loferer-Krößbacher et al. (1998). Values are always means of at least 200 individual measurements

\section{DISCUSSION}

\section{Abiotic environmental conditions at the investigation sites}

The sites OMV 11 and PI 92, which are located upgradient and downgradient from the actual landfill area, appeared to be typical oligotrophic, pristine groundwater sites in terms of basic physical and chemical variables (Table 1). In contrast, the landfill site OMV 5 was characterized by high DOC values accompanied by low oxygen concentrations (Table 1), most probably a result of microbial consumption. High nitrogen concentrations appeared in the form of ammonium, which indicated pronounced ammonification while the parallel low nitrate indicated denitrification activities. High iron values were suggested to result from the natural sedimentary background, buried car wrecks via iron reduction during periods of anoxia. At low $\mathrm{pH}(<6)$, along with low oxygen concentrations, the reoxidation of Fe(II) is slow (Stumm \& Morgan 1996), which may explain the high iron concentrations in solution with the simultaneous presence of trace amounts of oxygen. HOC and monoaromatic hydrocarbons such as BTEXs were found in the nanomolar range (Table 1). The uncoupled groundwater table fluctuations observed for the landfill and the surrounding aquifer indicate that parts of the landfill aquifer were hydrologically not well connected with the adjacent aquifer (Fig. 3).

\section{The ISSEM}

The ISSEM is aimed at a better understanding of the distribution and ecology of subsurface microorganisms. It was designed for the simultaneous inves-

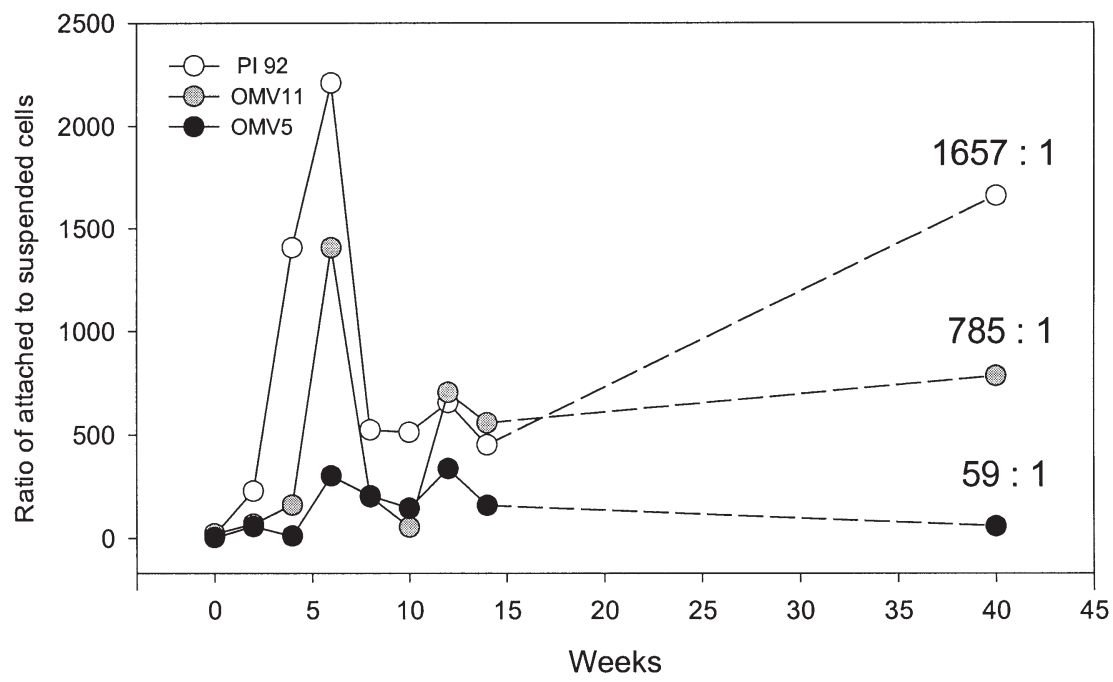

Fig. 6. Ratios of attached to suspended bacteria for the exposed sediments at the 3 investigation sites over an investigation period of $14 \mathrm{wk}$ and an additional sampling after a total incubation period of 10 mo. Values are means \pm SD 
tigation of suspended and attached microbial communities in shallow saturated aquifers. It combines the introduction of a natural substratum to the saturated subsurface and - contrary to the classical approach in well water - its exposure to true groundwater, which is pumped through the microcosm at flow rates comparable to natural conditions. Exposed sediments are therefore suggested to be exclusively colonized by indigenous groundwater microorganisms, and the subsequent development of biofilms, as well as the distribution of the microbes, can be followed over time by subsampling porewater and sediment from the microcosm. The only prerequisite for the application of the ISSEM is a multi-level monitoring well with an appropriate inner diameter $(\geq 5 \mathrm{~cm})$. At present, a major drawback of the system is the subsampling of sediment, which generally takes 2 to $3 \mathrm{~min}$ and requires withdrawal of the microcosm from the well. Thus, the brief disturbance of the microbes associated with the incubated sediment does not allow the current version of our ISSEM to be applied to strictly anoxic environments. Consequently, the data obtained at the temporarily hypoxic landfill site have to be interpreted with care, although oxygen concentrations never dropped to zero during our field experiments. A similar idea of a groundwater microcosm, i.e. the exposure of substratum to freshly pumped groundwater, was also stressed by Dodds et al. (1996). The so-called microcosm for aquifer experiments (MAX) consisted of a box filled with substratum that was continuously flushed with freshly pumped groundwater from a well. As the MAX stays outside the aquifer, it requires relatively high flowthrough rates of pumped groundwater to keep in situ temperature conditions.

\section{Groundwater versus well water}

Preliminary investigations carried out at PI 92 and OMV 11 in spring 1998 showed no significant difference between the 2 sites with respect to the total number of suspended bacteria in aquifer porewater (true groundwater) and bacteria in the well water, whereas the abundance of suspended cells was found to be higher in well water compared with the aquifer water at each site (data not shown). During the time of sediment exposure (40 wk), the bacterial abundance in well water at OMV 11 was found to be on average 6 times higher than cell densities observed in the pristine true groundwater (PI 92) (Table 2). These results clearly support earlier findings (McNabb \& Mallard 1984, Hirsch \& RadesRohkohl 1988, 1990, Hirsch et al. 1992) and emphasize that well water samples are not representative of groundwater.

\section{Colonization of exposed sediments}

In oligotrophic aquatic environments, such as the pristine saturated subsurface, growth at sediment surfaces is hypothesized to be a selective advantage compared to life in free solution (Kjelleberg \& Hermansson 1984, Bachofen et al. 1998). Macromolecules and organic compounds tend to accumulate at surfaces, which subsequently may lead to better access to nutrients (Zobell 1943, Marshall 1976, Mortland 1985). Limiting nutrients may further become available by dissolution of the mineral surface subsequent to colonization (Rogers et al. 1998, Bennett et al. 2000). Attached microorganisms furthermore may form synergistic communities, which can perform combined processes that individual species cannot (Fletcher 1984, Beveridge et al. 1997). Last but not least, biofilms may provide protection against toxins and shelter from predation (Caron 1987). For almost 50 yr, there has been evidence that attached bacterial communities dominate the pristine subsurface by numbers and biomass as compared to their suspended counterparts. Even organically polluted aquifers seem to be dominated by the attached microbial community, although nutrients may be present in excess (Harvey et al. 1984). Ratios of attached to suspended bacteria, reported for subsurface environments, range from 4:1 (Wolters \& Schwartz 1956) to 10 000:1 (Albrechtsen 1994, DVWK 1997). Similar observations were made in laboratory microcosm studies (Holm et al. 1992, Lehman et al. 2001a).

Regardless of the different nutrient conditions, incubated sediments were rapidly colonized by bacteria at all 3 investigation sites. Colonization patterns were highly similar at the nutrient-poor sites PI 92 and OMV 11, both peaking in number of attached bacteria after 6 wk of exposure (Fig. 4B). A similar picture was obtained by Marxsen (1982), who followed the colonization of sediments incubated in well water of a pristine sandy aquifer. In contrast, colonization patterns at the landfill site (OMV 5) showed a stepwise increase in the number of attached bacteria with a maximum peak after $10 \mathrm{wk}$ of incubation (Fig. 4B). Such short-term maxima in total number of individuals during colonization of a new habitat, as observed at all 3 investigated sites, are well known from various fields of ecology and have been found frequently in comparable studies of bacterial attachment to exposed surfaces in aquatic environments (Marxsen 1982, Golladay \& Sinsabaugh 1991, Scholz \& Boon 1993, Claret 1998a). Interspecific competition, the development of a multi-species community and the depletion of initial nutrient pools, together with limited transport or the establishment of a population of grazing predators, may cause a subsequent balance in 
the number of attached microorganisms at a much lower level.

As shown for marine sediments, bacteria colonize only a proportion of the available grain surface area and are therefore considered not to be limited by space (Hargrave 1972, Weise \& Rheinheimer 1978). Assuming a mean surface area of 100 to $300 \mathrm{~cm}^{2} \mathrm{~g}^{-1}$ for the coarse sand fraction used in our ISSEM study (Leichtfried 1985) and a mean area of $0.5 \mu^{2}$ covered by 1 typical bacterial cell, it would take 2 to $6 \times 10^{10}$ cells to form a unicellular layer. The total number of attached bacteria in our microcosms, as determined after 40 wk of incubation, would therefore correspond to a surface coverage of 0.1 to $0.4,0.3$ to 0.9 and 1 to $3 \%$ at PI 92, OMV 11 and OMV 5, respectively. Yamamoto \& Lopez (1985) reported $\leq 1 \%$ and Weise \& Rheinheimer (1978) found $<5 \%$ of the total grain surface to be populated by bacteria in marine sands. Therefore, factors other than surface availability must limit microbial colonization of sediments. The mineral composition of the solid matrix may be one important factor (Scholl et al. 1990, Rogers et al. 1998). Bennet et al. (2000) observed bacterial colonization on feldspars and quartz, poor colonization on calcite and no colonization on dolomite surfaces. Sediment used in our ISSEM studies, which is suggested to contain mainly calcite and quartz, was obviously acceptable for bacterial colonization.

\section{Distribution of bacteria in the subsurface}

It has already been mentioned above that attachment to particle surfaces is suggested to favor bacterial survival and growth, especially at low nutrient conditions (see also Marshall 1988). With increasing nutrient concentrations, on the other hand, a decrease in the attached versus suspended cell ratio occurs, which has been demonstrated by Bengtsson (1989) in laboratory microcosms fed by groundwater. Our field data support these findings. The oligotrophic subsurface site PI 92 had highest ratios of attached to suspended cells, followed by the well water site OMV 11, while the lowest ratios were calculated for the contaminated aquifer (OMV 5) (Fig. 6). Similar observations from contaminated aquifers have been documented by Harvey et al. (1984), Harvey \& George (1987) and Godsy et al. (1992). Ratios of attached to suspended cells are therefore suggested to be indicative of actual nutritional conditions in aquatic sedimentary environments (Griebler et al. 2001). However, large differences between the final ratios of attached to suspended bacteria at the investigated sites must be handled with caution. Calculating the percentage of suspended relative to attached cells, i.e.
$0.06 \%$ at PI $92,0.13 \%$ at OMV 11 and $1.7 \%$ at OMV 5 , and considering confidence limits, no significant difference is found anymore because of high SDs in bacterial counts.

As a close relation was observed between the number of attached cells and the surface area of sediment particles on a volume basis (Griebler et al. 2001 and references therein), the major part of the bacterial cells is associated with smaller grain-sized fractions. In a study by Holm et al. (1992), the silt and clay-sized fraction accounted for only $3.9 \%$ of sand and gravel aquifer material but carried 58 to $95 \%$ of the total bacterial biomass. This finding is also in agreement with investigations of Albrechtsen (1994), who detected 91.9 to $100 \%$ of the bacteria in the 1.2 to $100 \mu \mathrm{m}$ sediment fraction, and Harvey et al. (1984), who reported that $67 \pm 8 \%$ of the total microbial population was present in the $<20 \mu \mathrm{m}$ fraction and $23 \pm 6 \%$ in the 20 to $60 \mu \mathrm{m}$ fraction of an aquifer sediment. As we used exclusively the coarse sand fraction (600 to $2000 \mu \mathrm{m}$ ) in the recent exposure experiments, the real ratios of attached to unattached bacteria may even be 1 to 2 orders of magnitude higher.

\section{Attached bacterial biomass}

Data on the cell dimension and carbon content of subsurface bacteria are scarce. Marxsen (1982) reported medium cell volumes of attached and suspended bacteria from a pristine sandy aquifer ranging from 0.071 to 0.12 and 0.061 to $0.081 \mu^{3}$, respectively. Converting these biovolumes to cell carbon by applying the same conversion factor as that used in our study (Loferer-Krößbacher et al. 1998) results in carbon values of 22 to 35 and 20 to $25 \mathrm{fg} \mathrm{C} \mathrm{Cell}^{-1}$, respectively. A few more data are documented for suspended bacteria from unpolluted and polluted groundwater of sandy and gravelly deposits ranging from 0.076 to $0.21 \mu^{3}$ (Marxsen 1981), equivalent to 24-58 $\mathrm{fg} \mathrm{C}_{\mathrm{Cell}}^{-1}$. Carbon content of attached bacteria from PI 91 and OMV 11, i.e. $20.9 \pm 22.8$ and $23.7 \pm 23.4 \mathrm{fg} \mathrm{C} \mathrm{cell}^{-1}$, respectively, match fairly well with these data. Attached bacteria from the landfill site were found to be considerably smaller. Unfortunately, no image analysis data of the suspended bacterial community are available for a further comparison between the attached and the suspended community. Some studies show attached cells to be larger than suspended ones (e.g. Marxsen 1982). From our personal experience, this was also true for PI 92 and OMV 11 samples, but groundwater samples from the landfill often contained a conspicuous amount of filamentous bacteria and big spherical cells packed into small aggregates, which were not detected in the parallel sediment samples. 


\section{Ecological role of biofilms in the subsurface}

Meio- and macroorganisms present in the subsurface (e.g. Isopoda, Amphipoda, Ostracoda, Copepoda, Nematoda) feed mainly on biofilms (Ward et al. 1998). Nevertheless, because of limited pore space and the scarcity of food, as well as other forcing factors, these organisms appear in only low numbers and biomass. Therefore, their contribution to the cycling of matter seems to be only marginal. Protists may be even more effective consumers of the bacterial biomass, but little information is available on their role in microbial food webs of benthic marine and freshwater habitats. Nevertheless, it has already been shown that protists may substantially contribute to the flux of organic matter by grazing on the benthic bacterial community (Fenchel 1975, Kemp 1988, Hondeveld et al. 1992, Starink et al. 1994). For subsurface systems, there is almost no information available concerning microbial food webs. In groundwater samples from PI 92 and OMV 11, we frequently detected heterotrophic nanoflagellates (HNF) and ciliates. Nevertheless, their abundance was comparably low, and preliminary grazing experiments failed (Slezak et al. unpubl.). Considerable numbers of protists have been found at the landfill site OMV 5 only (data not shown). High numbers of protists in organically contaminated aquifers have also been reported elsewhere (e.g. Kinner et al. 1993, Sinclair et al. 1993). Grazing on attached bacteria was proved to be an effective feeding mode for benthic protists (Starink et al. 1994, Eisenmann et al. 1998), and both stimulating and inhibiting effects of protozoan grazing upon the sediment bacterial community have been found (DeLeo \& Baveye 1997, Kinner et al. 1998, Kota et al. 1999). Although bacterial communities in pristine aquifers seem to be bottom-up controlled, top-down effects from protists and meio- and macroorganisms grazing on attached bacteria may occur to a certain extent and become more important with a switch from oligotrophic to nutrient-rich conditions.

Acknowledgements. Thanks to D. L. Danielopol for constant support and discussion. We are further grateful to colleagues from the Provincial Government of Salzburg, Section of Water Protection, especially to P. Jäger, and the Section of Meteorology, who kindly provided precipitation data. R. Niederreiter (UWITEC) provided substantial help in the construction of the ISSEM. T. Posch, S. Klammer and S. Andreatta are acknowledged for helping with image analysis. Thanks to M. Hahn and R. Meckenstock for critical comments on former drafts of the manuscript. Critical comments of 3 anonymous reviewers are acknowledged. Financial support was provided by the Austrian National Bank (grant no. 6829).

\section{LITERATURE CITED}

Albrechtsen HJ (1994) Distribution of bacteria, estimated by a viable count method, and heterotrophic activity in different size fractions of aquifer sediment. Geomicrobiol J 12: 253-264

Alfreider A, Krössbacher M, Psenner R (1997) Groundwater samples do not reflect bacterial densities and activity in subsurface systems. Water Res 31:832-840

Amy PS, Haldeman DL, Ringelberg D, Hall DH, Russell C (1992) Comparison of identification systems for the classification of bacteria isolated from water and endolithic habitats within the deep subsurface. Appl Environ Microbiol 58:3367-3373

Bachofen R, Ferloni P, Flynn I (1998) Microorganisms in the subsurface. Microbiol Res 153:1-22

Bekins BA, Godsy EM, Warren E (1999) Distribution of microbial physiologic types in an aquifer contaminated by crude oil. Microb Ecol 37:263-275

Bengtsson G (1989) Growth and metabolic flexibility in groundwater bacteria. Microb Ecol 18:235-248

Bennett PC, Hiebert FK, Rogers JR (2000) Microbial control of mineral-groundwater equilibria: macroscale to microscale. Hydrol J 8:47-62

Beveridge TJ, Makin SA, Kadurugamuwa JL, Li Z (1997) Interactions between biofilms and the environment. FEMS Microbiol Rev 20:291-303

Caron DA (1987) Grazing of attached by heterotrophic microflagellates. Microb Ecol 13:203-218

Claret C (1998a) A method based on artificial substrates to monitor hyporheic biofilm development. Int Rev Hydrobiol 83:135-143

Claret C (1998b) Hyporheic biofilm development on artificial substrata, as a tool for assessing trophic status of aquatic systems: first results. Ann Limnol 34:119-128

Danielopol DL, Niederreiter R (1987) A sampling device for groundwater organisms and oxygen measurement in multi-level monitoring wells. Stygologia 3:252-263

DeLeo PC, Baveye P (1997) Factors affecting protozoan predation of bacteria clogging laboratory aquifer microcosms. Geomicrobiol J 14:127-149

Dodds WK, Randel CA, Edler CC (1996) Microcosms for aquifer research: application to colonization of various sized particles by ground-water microorganisms. Ground Water 34:756-759

Doig F, Sherwood-Lollar B, Ferris FG (1996) Microbial communities in deep Canadian Shield groundwaters: an in situ biofilm experiment. Geomicrobiol J 13:91-102

DVWK (Deutscher Verband für Wasserwirtschaft und Kulturbau) (1997) Parameter und Methoden der biologischen Charakterisierung des Untergrundes: Feststoffe und Wasser. Schriftenreihe Dtsch Verb Wasserwirtsch Kulturbau 120

Eisenmann H, Harms H, Meckenstock R, Meyer EI, Zehnder AJB (1998) Grazing of a Tetrahymena sp. on adhered bacteria in percolated columns monitored by in situ hybridization with fluorescent oligonucleotide probes. Appl Environ Microbiol 64:1264-1269

Fenchel T (1975) The quantitative importance of the benthic microfauna of an arctic tundra pond. Hydrobiologia 46: 445-464

Fletcher M (1984) Comparative physiology of attached and freeliving bacteria. In: Marshall K (ed) Microbial adhesion and aggregation. Springer Verlag, Heidelberg, p 223-232

FSPO (Federal Soil Protection Ordinance) (1999) Federal Soil Protection Ordinance (Bundes-Bodenschutz Verordnung), Germany 
Godsy EM, Goerlitz DF, Grbic-Galic D (1992) Methanogenic biodegradation of creosote contaminants in natural and simulated groundwater ecosystems. Ground Water 30: 232-242

Gold T (1992) The deep, hot biosphere. Proc Natl Acad Sci USA 89:6045-6049

Golladay SW, Sinsabaugh RL (1991) Biofilm development on leaf and wood surfaces in a boreal river. Freshw Biol 25: 437-450

Griebler C, Mindl B, Slezak D (2001) Combining DAPI and SYBR Green II for the enumeration of total bacterial numbers in aquatic sediments. Int Rev Hydrobiol 86:453-465

Griffin WT, Phelps TJ, Colwell FS, Fredrickson JK (1997) Methods for obtaining deep subsurface microbiological samples by drilling. In: Amy PS, Haldeman DL (eds) The microbiology of the deep subsurface. Lewis Publishers, Boca Raton, p 23-44

Hargrave BT (1972) Aerobic decomposition of sediment and detritus as a function of particle surface area and organic content. Limnol Oceanogr 17:583-596

Harvey RW, George LH (1987) Growth determinations for unattached bacteria in a contaminated aquifer. Appl Environ Microbiol 53:2992-2996

Harvey RW, Smith RL, George L (1984) Effect of organic contamination upon microbial distribition and heterotrophic uptake in a Cape Cod, Mass., aquifer. Appl Environ Microbiol 48:1197-1202

Hazen TC, Jimenez L, Lopez de Victoria G, Fliermans CB (1991) Comparison of bacteria from deep subsurface sediments and adjacent groundwater. Microb Ecol 22:293-304

Hirsch P, Rades-Rohkohl E (1988) Some special problems in the determination of viable counts of groundwater microorganisms. Microb Ecol 16:99-113

Hirsch P, Rades-Rohkohl E (1990) Microbial colonization of aquifer sediment exposed in a groundwater well in northern Germany. Appl Environ Microbiol 56:2963-2966

Hirsch P, Rades-Rohkohl E (1992) The natural microflora of the Segeberger Forst aquifer system. In: Matthess G, Frimmel FH, Hirsch P, Schultz HD, Usdowski E (eds) Progress in hydrogeochemistry. Springer Verlag, Berlin, p 390-412

Hirsch P, Rades-Rohkohl E, Kölbel-Boelke J, Nehrkorn A, Schweisfurth R, Selenka F, Hack A (1992) Methods of studying ground water microbiology: critical evaluation and method suggestions. In: Matthess G, Frimmel FH, Hirsch P, Schultz HD, Usdowski E (eds) Progress in hydrogeochemistry. Springer Verlag, Berlin, p 325-333

Holm PE, Nielsen PH, Albrechtsen HJ, Christensen TH (1992) Importance of unattached bacteria and bacteria attached to sediment in determining potentials for degradation of xenobiotic organic contaminations in an aerobic aquifer. Appl Environ Microbiol 58:3020-3026

Hondeveld BJM, Bak RP, van Duyl FC (1992) Bacterivory by heterotrophic nanoflagellates in marine sediments measured by uptake of fluorescently labled bacteria. Mar Ecol Prog Ser 89:63-71

Kemp PF (1988) Bacterivory by benthic ciliates: significance as a carbon source and impact on sediment bacteria. Mar Ecol Prog Ser 49:163-169

Kinner NE, Bunn A, Warren A, Harvey RW (1993) The distribution of protozoa in an organically contaminated aquifer. In: Eijsackers HJP, Hamers T (eds) Integrated soil and sediment research: a basis for proper protection. Kluwer Academic, Dordrecht, p 677-678

Kinner NE, Harvey RW, Blakeslee K, Novarino G, Meeker LD (1998) Size-selective predation on groundwater bacteria by nanoflagellates in an organic-contaminated aquifer.
Appl Environ Microbiol 64:618-625

Kjelleberg S, Hermansson N (1984) The effect of interfaces on small starved marine bacteria. Appl Environ Microbiol 48: 497-503

Kölbel-Boelke J, Nehrkorn A (1992) Heterotrophic bacterial communities in the Bocholt aquifer system. In: Matthess G, Frimmel FH, Hirsch P, Schultz HD, Usdowski E (eds) Progress in hydrogeochemistry. Springer Verlag, Berlin, p 378-390

Kölbel-Boelke J, Anders EM, Nehrkorn A (1988) Microbial communities in the saturated groundwater environment II: Diversity of bacterial communities in a pleistocene sand aquifer and their in vitro activities. Microb Ecol 16:31-48.

Kota S, Borden RC, Barlaz MA (1999) Influence of prototoan grazing on contaminant biodegradation. FEMS Microbiol Ecol 29:179-189

Lehman RM, Colwell FS, Bala GA (2001a) Attached and unattached microbial communities in a simulated basalt aquifer under fracture- and porous-flow conditions. Appl Environ Microbiol 67:2799-2809

Lehman RM, Roberto FF, Early D, Bruhn DF, Brink SE, O'Connell SP, Delwiche ME, Colwell FS (2001b) Attached and unattached bacterial communities in a 120 meter corehole in an acidic, crystalline rock aquifer. Appl Environ Microbiol 67:2095-2106

Leichtfried M (1985) Organic matter in gravel streams (Project Ritrodat-Lunz). Verh Int Ver Limnol 22:2058-2062

Loferer-Krößbacher M, Klima J, Psenner R (1998) Determination of bacterial cell dry mass by transmission electron microscopy and densitometric image analysis. Appl Environ Microbiol 64:688-694

Marshall KC (1976) Interfaces in microbial ecology. Harvard University Press, Cambridge

Marshall KC (1988) Adhesion and growth of bacteria at surfaces in oligotrophic habitats. Can J Microbiol 34:503-506

Marxsen J (1981) Bacterial biomass and bacterial uptake of glucose in polluted and unpolluted groundwater of sandy and gravelly deposits. Verh Int Ver Limnol 21: 1371-1375

Marxsen J (1982) Ein neues Verfahren zur Untersuchung der bakteriellen Besiedelung grundwasserführender sandiger Sedimente. Arch Hydrobiol 95:221-233

McNabb JF, Mallard GE (1984) Microbiological sampling in the assessment of groundwater pollution. In: Bitton $G$, Gerba CP (eds) Groundwater pollution microbiology. John Wiley \& Sons, New York, p 235-260

Mortland MM (1985) Interaction between organic molecules and mineral surfaces. In: Ward CH, Giger W, McCarty PL (eds) Ground water quality. John Wiley \& Sons, New York, p 370-386

Nielsen PH, Christensen TH, Albrechtsen HJ, Gillham RW (1996) Performance of the in situ microcosm technique for measuring the degradation of organic chemicals in aquifers. Ground Water Monit Rev 16:130-140

OMV Corp (1987) Deponieuntersuchung Anif (im Auftrag der Salzburger Landesregierung 16/01-1456/22-1986). OMV Corp, Salzburg, p 1-70

Porter KG, Feig YS (1980) The use of DAPI for identifying and counting aquatic microflora. Limnol Oceanogr 25:943-948

Posch T, Pernthaler J, Alfreider A, Psenner R (1997) Cellspecific respiration activity of aquatic bacteria studied with the tetrazolium reduction method, cytoclear slides, and image analysis. Appl Environ Microbiol 63:867-873

Rogers JR, Bennett PC, Choi WJ (1998) Feldspars as a source of nutrients for microorganisms. Am Mineral 83: $1532-1540$

Russell CE (1997) The collection of subsurface samples by 
mining. In: Amy PS, Haldeman DL (eds) The microbiology of the deep subsurface. Lewis Publishers, Boca Raton, p 45-59

Scholl MA, Mills AL, Herman JS, Hornberger GM (1990) The influence of mineralogy and solution chemistry on the attachment of bacteria to representative aquifer materials. J Contam Hydrol 6:321-336

Scholz O, Boon PI (1993) Biofilm development and extracellular enzyme activities on wood in billabongs of south-eastern Australia. Freshw Biol 30:359-368

Shati MR, Ronen D, Mandelbaum RT (1996) Method for in situ study of bacterial activity in aquifers. Environ Sci Technol 30:2646-2653

Sinclair JL, Kampbell DH, Cook ML, Wilson JT (1993) Protozoa in subsurface sediments from sites contaminated with aviation gasoline or jet fuel. Appl Environ Microbiol 59: 467-472

Starink M, Krylova IN, Bär-Gilissen MJ, Bak RP, Cappenberg TE (1994) Rates of benthic protozoan grazing on free and attached sediment bacteria measured with fluorescently stained sediment. Appl Environ Microbiol 60:2259-2264

Stumm W, Morgan JJ (1996) Aquatic chemistry. John Wiley \&

Editorial responsibility: Karel Šimek,

České Budějovice, Czech Republic
Sons, New York

Ward JV, Bretschko G, Brunke M, Danielopol D, Gibert J, Gonser T, Hildrew AG (1998) The boundaries of river systems: the metazoan perspective. Freshw Biol 40:531-569

Weise W, Rheinheimer G (1978) Scanning electron microscopy and epifluorescence investigation of bacterial colonization of marine sand sediments. Microb Ecol 4: $175-188$

Whitman WB, Coleman DC, Wiebe WJ (1998) Prokaryotes: the unseen majority. Proc Natl Acad Sci USA 95: 6578-6583

Wilson JT, McNabb JF, Balkwill DL, Ghiorse WC (1983) Enumeration and characterization of bacteria indigenous to a shallow water-table aquifer. Ground Water 21:134-142

Wolters N, Schwartz W (1956) Untersuchungen über Vorkommen und Verhalten von Mikroorganismen in reinen Grundwässern. Arch Hydrobiol 51:500-541

Yamamoto N, Lopez G (1985) Bacterial abundance in relation to surface area and organic content of marine sediments. J Exp Mar Biol Ecol 90:209-220

Zobell CE (1943) The effect of solid surfaces upon bacterial activity. J Bacteriol 46:39-59

Submitted: June 2, 2001; Accepted: April 9, 2002

Proofs received from author(s): June 19, 2002 